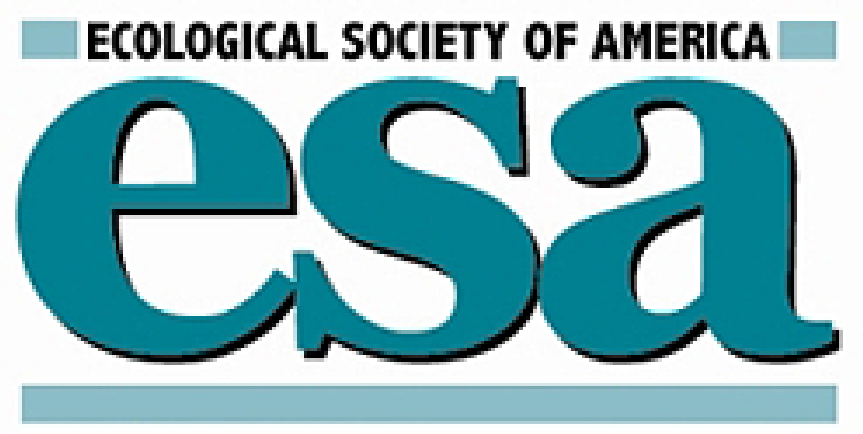

Diurnal and Seasonal Water Relations of the Desert Phreatophyte Prosopis Glandulosa (Honey Mesquite) in the Sonoran Desert of California

Author(s): Erika Tallak Nilsen, M. Rasoul Sharifi, Philip W. Rundel, Wesley M. Jarrell and Ross A. Virginia

Source: Ecology, Vol. 64, No. 6 (Dec., 1983), pp. 1381-1393

Published by: Ecological Society of America

Stable URL: http://www.jstor.org/stable/1937492

Accessed: 13/03/2014 09:53

Your use of the JSTOR archive indicates your acceptance of the Terms \& Conditions of Use, available at http://www.jstor.org/page/info/about/policies/terms.jsp

JSTOR is a not-for-profit service that helps scholars, researchers, and students discover, use, and build upon a wide range of content in a trusted digital archive. We use information technology and tools to increase productivity and facilitate new forms of scholarship. For more information about JSTOR, please contact support@jstor.org. 
Copyright by the Ecological Society of America. Erika Tallak Nilsen, M. Rasoul Sharifi, Philip W. Rundel,

Wesley M. Jarrell, and Ross A. Virginia 1983. Diurnal and Seasonal Water Relations of the Desert Phreatophyte Prosopis Glandulosa (Honey Mesquite) in the Sonoran Desert of California. Ecology 64:1381-1393. http://

\title{
DIURNAL AND SEASONAL WATER RELATIONS OF THE DESERT PHREATOPHYTE PROSOPIS GLANDULOSA (HONEY MESQUITE) IN THE SONORAN DESERT OF CALIFORNIA ${ }^{1}$
}

\author{
ERik Tallak Nilsen \\ Department of Biology, Virginia Polytechnic Institute and State University, \\ Blacksburg, Virginia 2406I USA \\ M. Rasoul Sharifi and Philip W. Rundel 2 \\ Department of Ecology and Evolutionary Biology, University of California, \\ Irvine, California 92717 USA \\ AND \\ WeSLEy M. JaRRELl ANd Ross A. Virginia \\ Department of Soils and Environmental Sciences, University of California, \\ Riverside, California 92521 USA
}

\begin{abstract}
Diurnal and seasonal water relations were monitored in a population of Prosopis glandulosa var. torreyana in the Sonoran Desert of southern California. Prosopis glandulosa at this research site acquired its water from a ground water source 4-6 m deep. Measurements of diurnal and seasonal cycles of aboveground environmental conditions, soil moisture, and soil water potential (to $6 \mathrm{~m}$ depth) were taken to ascertain environmental water availability and water stress. Leaf water potential, leaf conductance, leaf transpiration, relative saturation deficit of leaves, osmotic potential, and turgor potential were measured to evaluate plant adaptations to environmental water stress. Soil water potential was low $(-4.0$ to $-5.0 \mathrm{MPa})$ in surface soil in relation to deep soil $(-0.2$ MPa). This difference was due to high surface soil salinity and low surface water content. The climatic conditions at the research site produced extreme water stress conditions in summer months when temperatures reached $50^{\circ} \mathrm{C}$, vapor pressure deficit (VPD) reached $8 \mathrm{kPa}$, and surface soil water potential was below $-4.5 \mathrm{MPa}$. Although considerable plant water stress developed in these trees (midday leaf water potential $-4.8 \mathrm{MPa}$ ), osmotic adjustment occurred and turgor was maintained on a diurnal and seasonal cycle. Prosopis glandulosa has adapted to avoid water stress by utilizing deep ground water, but this phreatophyte has also evolved physiological adaptations, such as osmotic adjustment and seasonally changing stomatal sensitivity to VPD, which result in greater tolerance of water stress.
\end{abstract}

Key words: leaf conductance; osmotic adjustment; phreatophyte; Prosopis glandulosa; Sonoran Desert; turgor potential; water relations.

\section{INTRODUCTION}

Studies of water relations which concern plants of desert regions have emphasized the adaptations of shrub species which allow tolerance of water stress (see Osmond et al. 1980). These adaptations, for example, cover morphological adjustment to water stress (Cunningham and Strain 1969, Smith and Nobel 1977, Ehleringer and Mooney 1983), photosynthetic adaptation (Strain 1969, Hellmuth 1971, Odening et al. 1974), spatial distribution of individuals (Fonteyn and Mahall 1978), and osmotic adjustment (Walter and Stadelman 1974, Bennert and Mooney 1979, Monson and Smith 1982). Although considerable research has been done on the water relations of desert shrubs and ephemerals (e.g., Gulmon and Mooney 1977, Mulroy and Rundel

\footnotetext{
1 Manuscript received 28 April 1982; revised 1 November 1982; accepted 9 November 1982.

2 Present address: Laboratory of Biomedical and Environmental Sciences, University of California, Los Angeles, California 90024 USA.
}

1977, Anderson and Szarek 1981), few studies have been concerned with the water relations of desert trees (e.g., Adams and Strain 1968, Haas and Dodd 1972, Szarek and Woodhouse 1976).

The phreatophytic species which has been most extensively studied in an ecological context is Prosopis glandulosa (mesquite). A large volume of available literature concerns the mechanisms to rid the landscape in Texas of this vigorous weed (see Parker and Martin 1952), while conversely, recent studies have evaluated the utility of mesquite as a crop for arid lands (Felker 1979, Nilsen et al. 1982). The water relation studies which concern mesquite have involved water use characteristics of communities in Texas and Arizona (e.g., McGinnes and Arnold 1939, Cable 1977, Webb et al. 1979). Few studies have evaluated the water relations of Prosopis (Haas and Dodd 1972, Nilsen et al. 1981) on an ecophysiological basis.

The available data suggest that phreatophytic species such as Prosopis avoid water stress in arid regions by tapping water at depth in soils. Prosopis roots have been found at a great depth $(52 \mathrm{~m})$ in soils (Phillips 
1963), and stands of Prosopis survive in regions with little to no recorded rainfall by tapping underground water resources (Mooney et al. 1980). There is evidence for several phreatophytic species (Olneya tesota, Cercidium floridum, Acacia greggii) which indicated that only minor water stress (water potential not below -2.0 $\mathrm{MPa}$ ) develops in desert phreatophytes (Adams and Strain 1968, Szarek and Woodhouse 1978, Monson and Smith 1982). Rainfall is relatively high for desert regions $(350 \mathrm{~mm} / \mathrm{yr})$ in these study areas, and only suggestive evidence was presented indicating whether the Olnea and Acacia were growing phreatophytically. In the cases where phreatophytic growth was conclusive for Prosopis, considerable water stress $(-4.0 \mathrm{MPa})$ has been measured in summer months (Mooney et al. 1980, Nilsen et al. 1981). Therefore, mechanisms of drought tolerance should exist. Because of the lack of intensive water relations information on desert phreatophytes, we believe that such a study on Prosopis could result in an understanding of the mechanisms of drought avoidance and drought tolerance in phreatophytic species.

\section{Study Site}

This research was carried out in a mesquite woodland dominated by Prosopis glandulosa in the Sonoran Desert of southern California. Harper's Well, our study site, lies at an elevation of $-30 \mathrm{~m}$ at the base of the Fish Creek Mountains, $15 \mathrm{~km}$ west of the southern tip of the Salton Sea (Fig. 1). Prosopis glandulosa, a tree or large shrub reaching $5 \mathrm{~m}$ in height, accounts for $>90 \%$ of the vegetation cover. The few other shrubs which are present (Larrea, Atriplex, Allenrolfia, Pluchea), account for $<4 \%$ coverage. Few ephemerals are present. The soils at Harper's Well are classified as a clay loam near the surface with lenses of sand and clay at depth (described in detail in Virginia and Jarrell 1983). There is a permanent, stable groundwater table which varies spatially between depths of 4 and $6 \mathrm{~m}$ (Meinzer 1927). Soil chemical characteristics are unusual with large quantities of nitrogen at the surface (Rundel et al. 1982, Virginia and Jarrell 1983). Harper's Well is a central research site for several ecosystem and ecophysiological studies including Prosopis water relations (Nilsen et al. 1981, 1982, 1983), nitrogen fixation (Shearer et al. 1983), nutrient cycling (Rundel et al. 1982, Virginia and Jarrell 1983), net primary production and biomass (Sharifi et al. 1982), and phenology (Sharifi et al. 1983) of a desert phreatophytic (Prosopis glandulosa) community.

\section{Methods and Materials}

Climatic measurements were taken diurnally on 12 occasions (approximately monthly) during 1980-1981. Temperatures of leaves $(n=5)$, air, and soil $(1 \mathrm{~m},-1$ $\mathrm{cm},-30 \mathrm{~cm}$ ) were measured hourly from 500 to 1900 Pacific Standard Time (PST) with copper constantan thermocouples. Similar cycles of measurements were

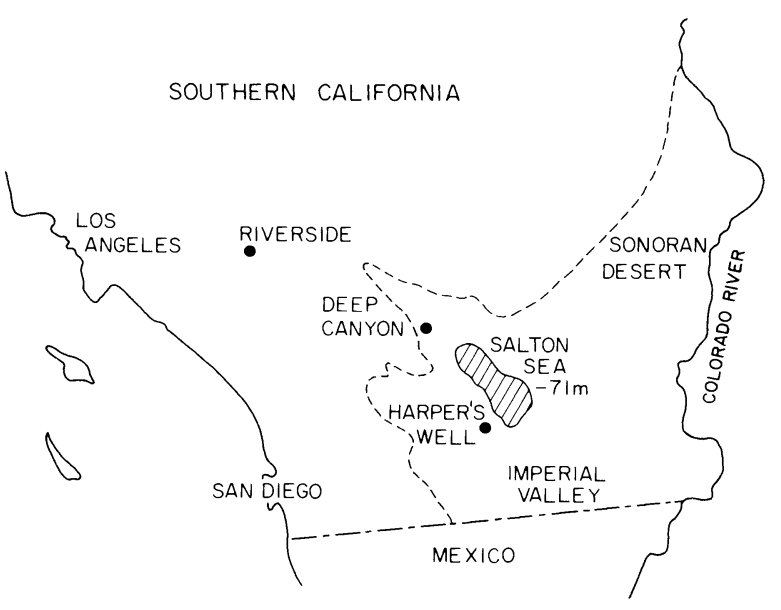

FIG. 1. Location of the primary research site, Harper's Well, in the Sonoran desert of southern California.

made for relative humidity (sling psychrometer), PAR (quantum sensor), and wind (hot-wire anemometer). The vapor pressure gradient was calculated from leaf temperature, air temperature, and relative humidity. Precipitation and seasonal air temperature were recorded at the official United States Department of Agriculture weather station (National Oceanic and Atmospheric Administration 1980, 1981) in Brawley (20 $\mathrm{km}$ south of the study site). Our field measurements indicate that maximum temperatures at Harper's Well are $\approx 3^{\circ} \mathrm{C}$ higher than those at Brawley. Soil water content was measured throughout the rooting profile at $25 \mathrm{~cm}$ increments to a maximum of $550 \mathrm{~cm}$ with the use of the neutron activation technique (Gardner 1965). Neutron probe access tubes were inserted under the canopies of five representative trees and midway between the selected trees. Measurements of volumetric moisture content were taken by the neutron activation technique approximately monthly from July 1980-September 1981.

Soil matric potential was determined for nine representative surface soil samples (both 0-30, and 30-60 $\mathrm{cm}$ depth) by use of a pressure plate apparatus (Gardner 1965). Curves relating soil volumetric water content to potentials as low as $-1.5 \mathrm{MPa}$ were constructed. Deep soil samples $(0-60 \mathrm{~cm}$ above groundwater level) were at or near saturation throughout the year. Soil osmotic potential was estimated from data on field soil water content (neutron probe) and the osmotic potential of soil saturation extracts measured using a vapor pressure osmometer. Surface soil osmotic potential was based on saturation extract data reported by Virginia and Jarrell (1983) and the osmotic potential of deep soil was based on saturation extracts of samples recovered from drilling 10 neutron access tubes. We assumed a linear inverse relationship between soil water content and the osmotic potential of the soil solution. This assumption ignores possible changes in 


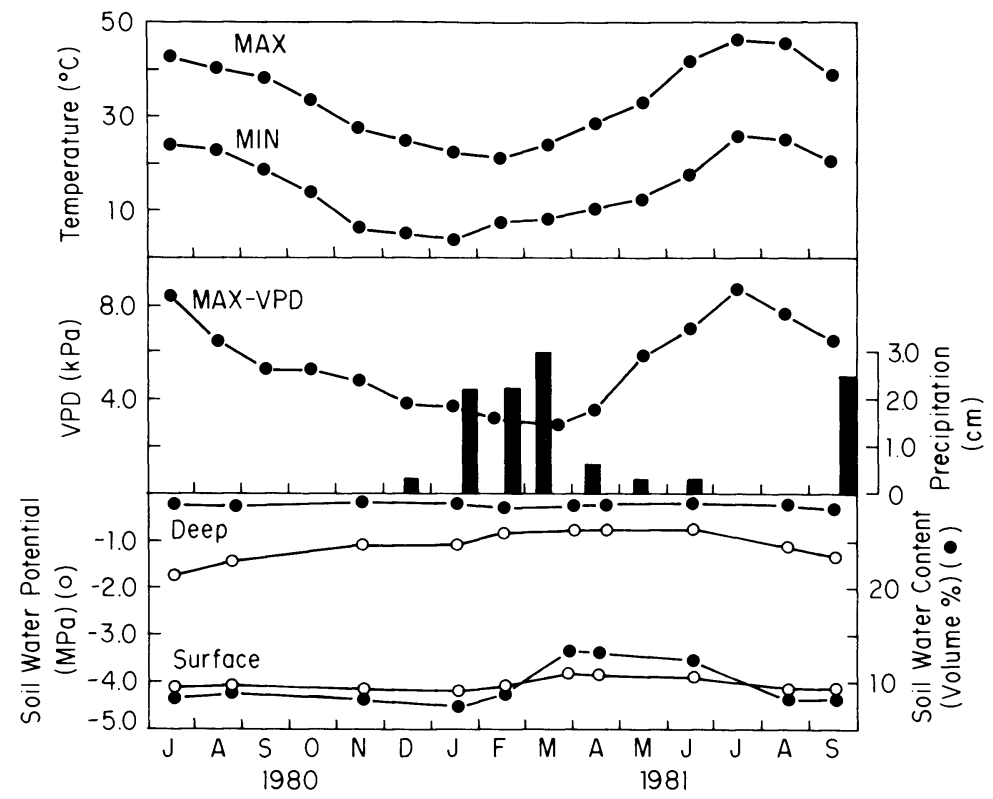

Fig. 2. Seasonal climatic conditions and soil water parameters.

the osmotic potential of the soil solution at low water content caused by precipitation of some salts.

All plant water relations were followed on five selected trees. The results are reported as means for the five individuals. Mean values are used because we are trying to characterize the diurnal and seasonal water relations of a population, not an individual. Some results will be presented on an individual plant basis to clarify a particular interaction of climate and water relations which is masked by average values. During the 12 diurnal cycles mentioned above, leaf water potential $\left(\psi_{l}\right)$ was determined with the use of a pressure chamber (Scholander et al. 1965). Water potential measurements were made in triplicate on each of five individuals every $2 \mathrm{~h}$ from 500 to 1900 (PST). Over a similar time course, leaf conductance $(g)$ and leaf transpiration were determined $(J)$. Leaf conductance was measured on five leaves of each sample individual $(n=$ 25 ), with a steady state porometer (LICOR-1600). Simultaneous measurements of transpiration were determined from the equation $J=g \cdot$ VPD, where transpiration $(J)$ is calculated from measurements of conductance and the vapor pressure deficit (VPD).

The predawn and midday leaf water potential was determined from July 1980 to September 1981 with a pressure chamber (four samples per individual; $n=$ 20). Twig and leaf samples were also collected on each sample date for pressure-volume (PV) determinations of water relations components (Tyree and Hammel 1972, Cheung et al. 1976, Nilsen et al. 1983). Samples were cut in the field, recut underwater, and rapidly transported to the lab for analysis. Techniques for PV analysis on phreatophytes have been previously described (Nilsen et al. 1983) and are based on those of
Tyree and Hammel 1972. On each sample date, five PV curves were formulated on each of four individuals. All PV curve samples were cut before dawn for uniformity. Diurnal osmotic adjustment was assessed by cutting similar, even-aged twig samples at midday as well as predawn for PV curve analyses.

\section{RESULTS}

\section{Climatic conditions}

Seasonal meteorological conditions at Harper's Well during 1980-1981 were characteristic of extreme warm deserts. Air temperature at Brawley increased from December to July reaching a mean maximum of $44^{\circ} \mathrm{C}$ (Fig. 2), with maximum diurnal temperatures $>50^{\circ}$ during July and August. Mean minimum temperatures never reached below $0^{\circ}$ and there were no individual air temperatures below $0^{\circ}$ during the measured diurnal cycles. Leaf temperature was within $1^{\circ}$ of air temperature on all diurnal cycles. Soil temperature of surface soil $(-1 \mathrm{~cm})$ reached $>80^{\circ}$ and minimum soil surface temperature was often below air temperature. Soil temperature below $-30 \mathrm{~cm}$ showed only slight seasonal variability around a mean of $25^{\circ}$.

The vapor pressure deficit followed a similar pattern to that of temperature (Fig. 2) reaching a maximum in July $(8.5 \mathrm{kPa})$. Annual precipitation at Brawley during $1980(65 \mathrm{~mm})$ and $1981(45 \mathrm{~mm})$ was slightly lower than the yearly average of $70 \mathrm{~mm}$ (Sharifi et al. 1983). Most precipitation occurred during the winter with only a few small summer storms in 1981, although normally August and September are the months when most precipitation occurs. Maximum daily photon flux was 53.3 $\mathrm{E} \cdot \mathrm{m}^{-2} \cdot \mathrm{d}^{-1}$. Seasonal soil moisture content is plotted as an average of all measurements (between and under 
trees) because active roots extend well beyond tree canopies. The soil moisture at depth remained fairly constant at $\approx 25 \%$ except during July 1980 and August 1981, when a significant decrease occurred (Fig. 2). In 1980 and 1981, surface soil water content was highest during the winter months (February-April) but the yearly average volumetric content was much lower (8$10 \%$ ) than that of the deep soil.

The surface soil had higher salinities than deep soil (Virginia and Jarrell 1983) due to limited infiltration and high evaporation rates. Therefore, the osmotic potential in surface soil was lower than that of deep soil throughout the year. Matric potentials for surface soils exceeded $-1.5 \mathrm{MPa}$, the limit of quantification using the pressure plate technique. The summation of osmotic and a minimum matric potential of $-1.5 \mathrm{MPa}$ indicates that surface soil water potential decreased below -4.5 MPa in July (Fig. 2), far lower than the water potential in deep soils $(-0.2 \mathrm{MPa})$. Results from the soil cores indicated that there was a root mat at the surface (above $-30 \mathrm{~cm}$ depth) and deep roots extending to -4 to $-6 \mathrm{~m}$, where they proliferate. Therefore, each portion of the dual rooting system of Prosopis experiences a widely different water potential regime. The seasonal surface soil water potentials plus seasonal meterological data all clearly indicate that June through August constitutes a period of extreme environmental water stress, particularly for the roots in surface soil.

\section{Phenology}

Diurnal cycles and seasonal water relations characteristics were influenced by both environmental conditions (as described above) and by leaf phenological characteristics. These seasonal trends of leaf production, leaf number, and leaf maturation are shown in Fig. 3. A majority of leaf production occurred during March and April and a secondary period of leaf production occurred in August on a much smaller scale. Leaves matured rapidly to full leaf area after production and initiated senescence, as defined by chlorosis or leaflet abscission, in September. Senescent leaves then remained on the branches until February and complete abscission did not occur until early March when the new set of leaves was being produced. The majority of leaves on the plants were of one cohort produced during late March to early April. This evenaged cohort of leaves was used exclusively for the water relations studies, and therefore influences of age on water relations were easily controlled. The second cohort of leaves produced in August was clearly identifiable through the morphological characteristics of the leaves.

\section{Diurnal cycles}

Diurnal cycles of environmental conditions support similar conclusions concerning the period of maximum environmental water stress. Of the 12 diurnal cycles

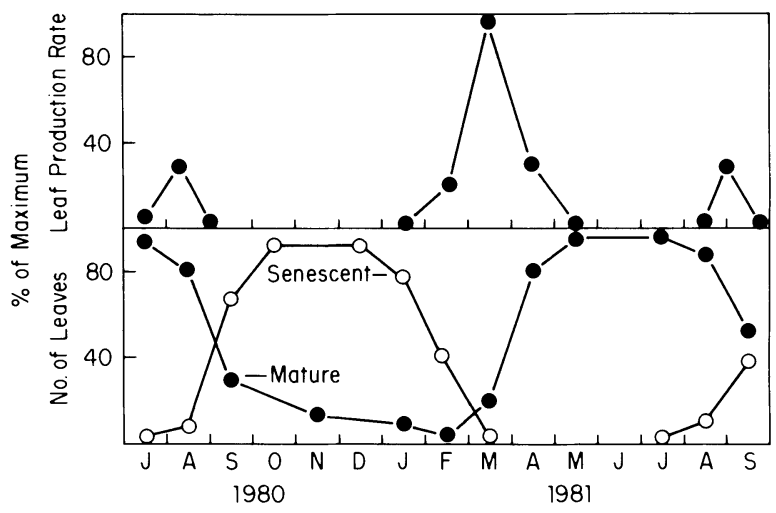

FIg. 3. Seasonal progression of leaf production rate and the number of senescent or mature leaves, as a percent of the yearly maximum, for Prosopis glandulosa.

measured, 4 are chosen to represent major characteristics of diurnal aboveground conditions. On all 4 dates presented, maximum air (Fig. 4) and leaf temperature was reached between 1300-1700. Leaf temperature was close to air temperature on all dates except in July, when midday leaf temperature rose $1^{\circ}$ above air temperature. Maximum surface soil temperature reached $80^{\circ}$ in July but only $30^{\circ}$ in February. Below $30 \mathrm{~cm}$ soil temperature varied little diurnally and from $15^{\circ}-25^{\circ}$ seasonally. Wind increased to a maximum in the afternoons, which is consistent with thermally driven wind currents.

The VPD also increased to a maximum between $1300-1500$ on all dates measured, with the difference between dawn and midday VPD largest during July and September. Only small variability in VPD occurred during the February diurnal cycle.

The photosynthetically active radiation (PAR) arriving at the leaf surface is little influenced by cloud cover since such cover is infrequent. Maximum PAR, occurring between $1100-1500$, is close to the potential maximum arriving at the earth's surfaces (Nobel 1977). Prosopis leaves track the motion of the sun during the morning and early afternoon hours, resulting in higher irradiance impinging on leaf surfaces than would be expected without solar tracking ability (Nilsen et al. 1981).

In general, leaf water potential decreases with increasing environmental water stress brought on by increasing irradiance, temperature, and vapor pressure deficit. Water potential at midday decreased to $\approx-4.0$ to $-4.5 \mathrm{MPa}$ after which it either increased or remained constant, except for the curve of diurnal water relations in February (Fig. 5). Minimum leaf water potential was only $-2.8 \mathrm{MPa}$ in February. Leaf conductance reaches a maximum early in the day (0800-0900), following which there is a general decline through the rest of the day (Fig. 5). There is an indication of stomatal closure at midday in the July and the May diur- 

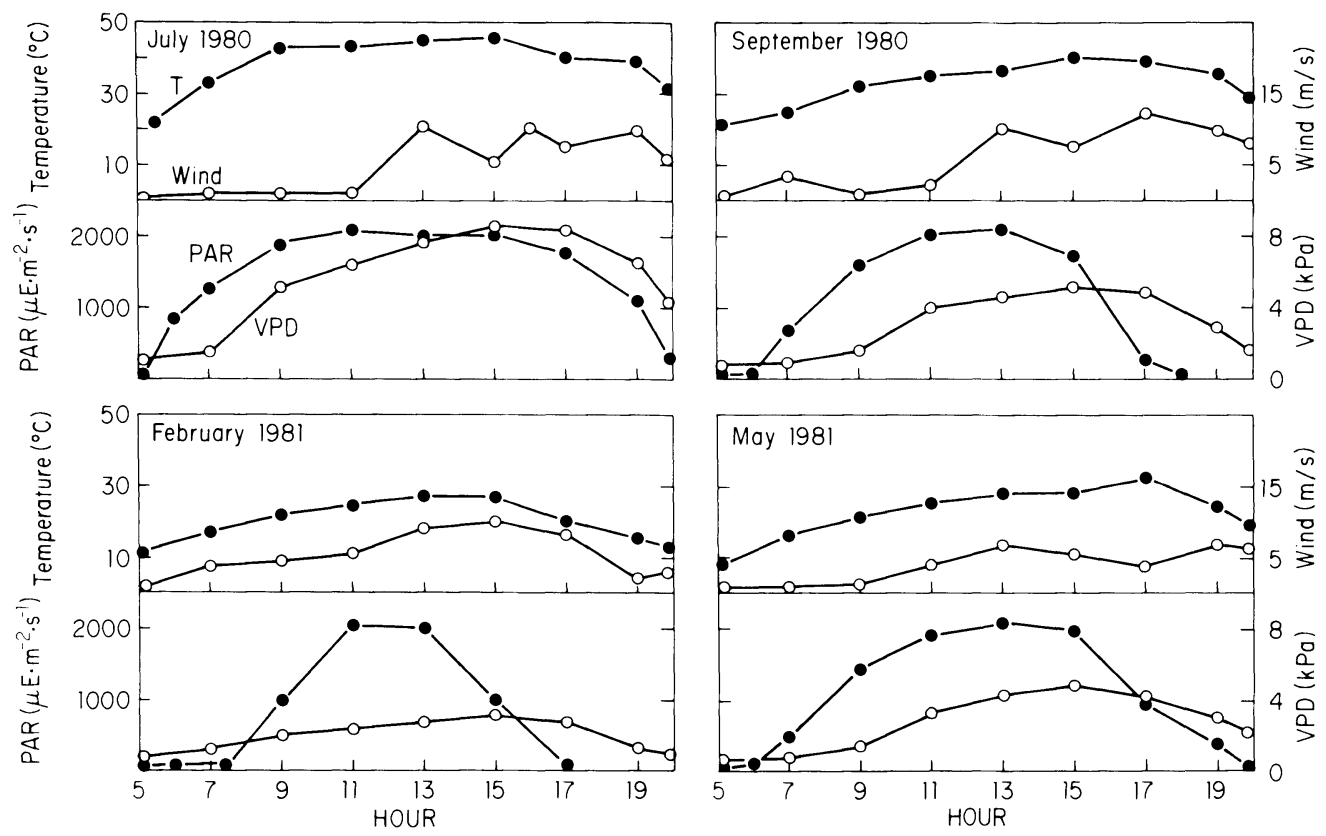

FIG. 4. Diurnal cycles of environmental conditions on four dates during 1980-1981.

nal cycles. The magnitude of the midday stomatal closure was variable among individuals; therefore, these cycles of mean leaf conductance mask some of the midday stomatal closure. While this midday stomatal closure is evident in the leaf conductance data, the pattern is not mimicked in the mean leaf water potential data. In fact, previously reported data (Nilsen et al. 1981) indicate that the leaf conductance is clearly better associated with the VPD than with water potential until a leaf water potential below $-4.0 \mathrm{MPa}$ is reached, at which time stomata close rapidly. The magnitude of secondary diurnal increases in stomatal conductance decreased in accordance with leaf age rather than with changes in diurnal meteorological conditions.

Diurnal cycles of transpiration were the product of VPD and conductance. Maximum transpiration occurred later in the day than maximum conductance because the VPD was low in the early morning. The midday depression in stomatal conductance was not reflected by decreasing transpiration (Fig. 5) because the VPD remained high (Fig. 4).

The interactions between leaf water potential, conductance, VPD, and transpiration are not clear in the mean values because the trees were not precisely in temporal agreement and the magnitude of the various water relations parameters varied between individuals. For this reason a diurnal cycle for one tree in August 1981 is presented in Fig. 6. As in July 1980, the PAR reaches a maximum by 1100 and remains full until 1500, after which time the light intensity decreases. The VPD increases slowly through the morn- ing hours, reaching a maximum of $8 \mathrm{MPa}$ by 1300 . The VPD then remains high, only decreasing slowly following 1700.

Leaf water potential $\left(\psi_{l}\right)$ oscillated over the course of the day. When $\psi_{l}$ decreased below -4.0 to -4.5 $\mathrm{MPa}$, it then began to increase again. Two such oscillations occurred during the diurnal cycle. The leaf conductance pattern followed that of leaf water potential. When leaf water potential decreased below $-4.0 \mathrm{MPa}$, stomata began to close, causing an increase in leaf water potential. Although the 1300 leaf water potential approached that of the morning, the resulting conductance at 1500 was much lower than that at 0700 . This was the result of higher VPD at midday than at 0700 . Also, even though the conductance decreased from 0900-1300, transpiration increased until 1100, and at 1300 a slight decrease occurred. This is likewise the result of increasing VPD. The secondary increase in conductance at 1500 caused a renewed increase in transpiration since the VPD was still high.

Leaf turgor potential was calculated from the measurements of leaf water potential and the pressurevolume relationship for August 1981 (data presented later in the article). Zero turgor is reached at 0800 at the time when stomata begin to close. Turgor potential then increases towards the afternoon (1000 to 1300) when leaf water potential increases as a result of reduced conductance. Thus, turgor potential increases as a result of reduced conductance. Turgor potential comes close to zero again at 1600 , following increased conductance. At dusk (1800) turgor is once again renewed in response to the decreasing conductance. 

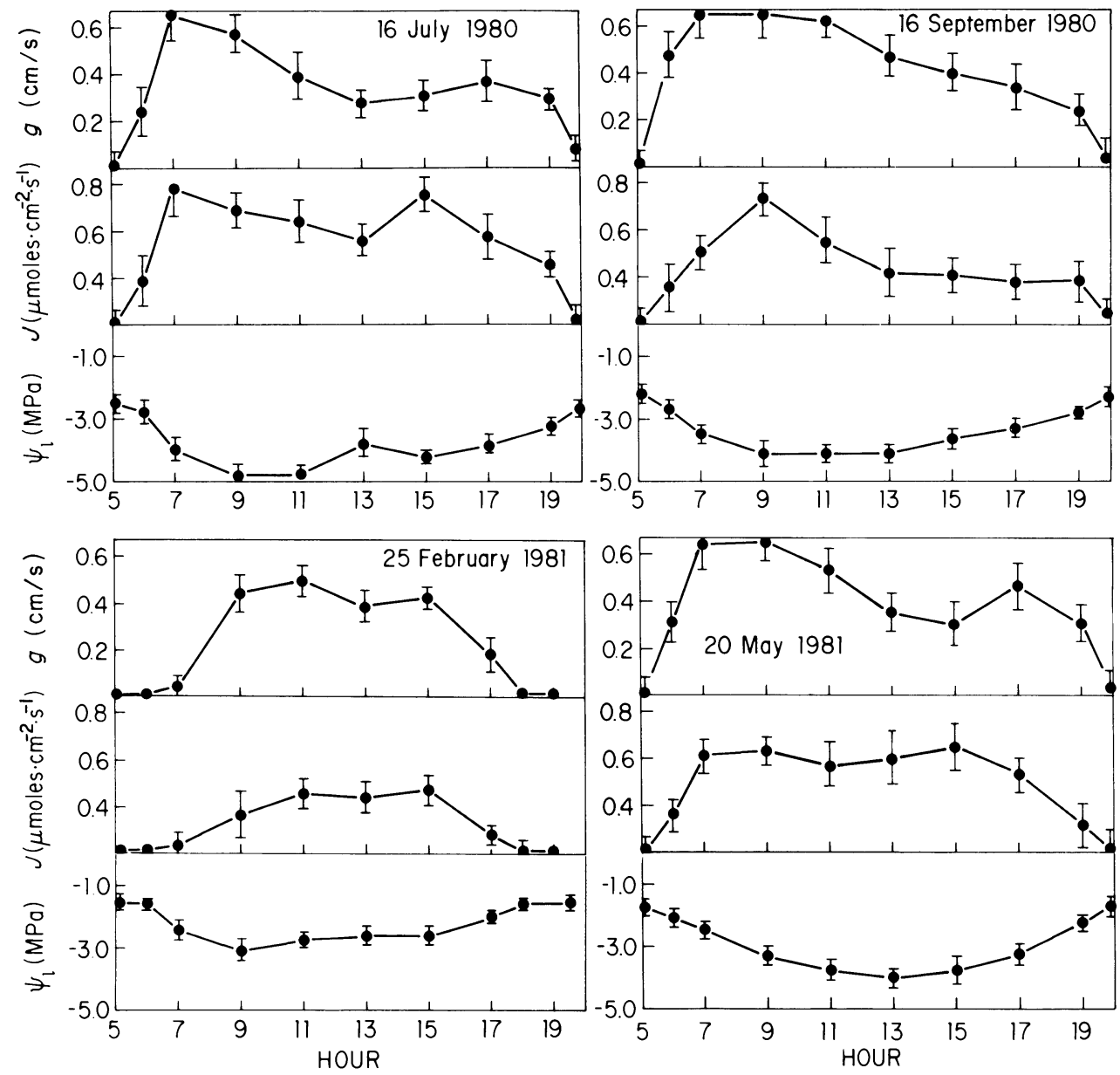

FIG. 5. Diurnal cycles of leaf conductance $(g)$, transpiration $(J)$, and leaf water potential $\left(\psi_{l}\right)$ for Prosopis glandulosa. Each point is a mean of five individuals with five samples per individual per time period.

\section{Seasonal parameters}

The seasonal water relations parameters reflect the important characteristics of the 12 diurnal cycles of water relations measured on this desert phreatophyte. Seasonal leaf water potential characteristics are shown in Fig. 7. Predawn leaf water potential remains fairly constant at $-2.5 \mathrm{MPa}$ throughout 1980-1981, except during February through March, when an increase of $1 \mathrm{MPa}$ occurs. Midday water potential is lowest during July-September, reaching as low as $-4.5 \mathrm{MPa}$. There is a gradual increase from September through February to a maximum value of $-1.7 \mathrm{MPa}$. The gradual increase is due partly to a reduction of environmental water stress and a reduction in plant leaf area (Fig. 3; and Sharifi et al. 1983). Because -4.0 MPa leaf water potential initiated stomatal closure (Fig. 6; and Nilsen et al. 1981) the number of hours below $-4.0 \mathrm{MPa}$ during a diurnal cycle is thought to be a good index of relative water stress for Prosopis glandulosa. During June-August there are nine or more hours $(64 \%$ of daylight hours) with a water potential below $-4.0 \mathrm{MPa}$.
This relative index of plant water stress decreases rapidly from September, to $0 \mathrm{~h}$ in January.

Several characteristics of diurnal leaf conductance and transpiration over the seasonal cycle are shown in Fig. 8. Maximum leaf conductance remains approximately constant $(>0.65 \mathrm{~cm} / \mathrm{s})$ from March through August. Following August, maximum leaf conductance decreases to a minimum during November through February, a period when most leaves are senescent and vapor pressure deficit is the lowest. Midday leaf conductance increased from July through January and remained low from late February through June. The difference between the maximum leaf conductance and the midday leaf conductance should be a significant indicator of plant water stress, since this index represents the magnitude of the midday stomatal closure in leaf conductance, previously considered a good indicator of plant water stress (Klepper 1968, Tenhunen et al. 1980). The maximum difference between midday and maximum leaf conductance occurred during May (Fig. 8). This index gradually in- 


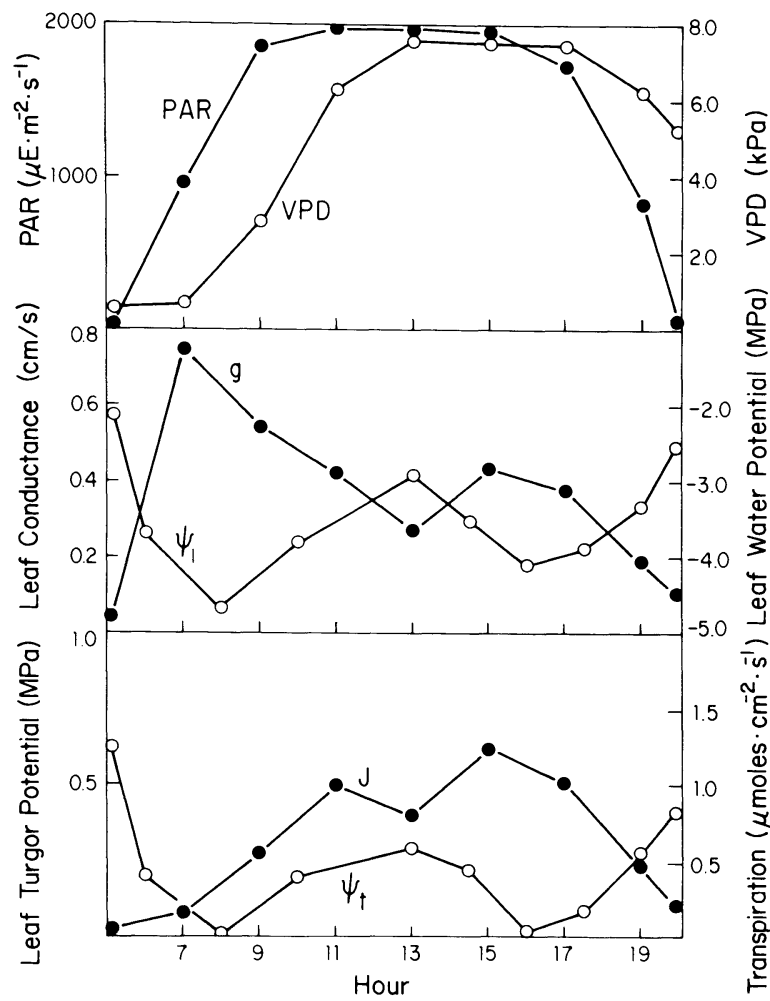

FIG. 6. Diurnal cycle of photosynthetically active radiation, vapor pressure deficit, leaf conductance $(g)$, leaf water potential $\left(\psi_{l}\right)$, transpiration $(J)$, and leaf turgor potential $\left(\psi_{t}\right)$ for a Prosopis glandulosa individual during August 1981.

creased from January through May and decreased thereafter. The midday decrease in leaf conductance has been found to be related to both plant water potential (e.g., Biscoe et al. 1976, Nilsen and Muller 1981) and vapor pressure deficit (Schulze et al. 1974). In this case, the maximum midday stomatal closure occurs 2 mo before the period of minimum leaf water potential (Fig. 7) and maximum vapor pressure gradient (Fig. 2). Leaf age influenced the magnitude of the midday stomatal closure; therefore, young leaves (April-May) respond more rapidly to smaller changes in VPD and leaf water potential, resulting in a greater midday decrease in leaf conductance. The seasonal variability in the midday stomatal closure may be strongly influenced by a variable sensitivity of stomata to changing VPD.

Regressions between VPD and leaf conductance were formulated for each diurnal cycle. These linear regressions were significant $(P=.05)$ and $r^{2}$ values ranged from 0.95 to 0.47 . Lower $r^{2}$ values were found during diurnal cycles which contained water potentials below $-4.5 \mathrm{MPa}$. Such low leaf water potentials were associated with rapid stomatal closure (Nilsen et al. 1981). The sensitivity of stomata to changes in VPD is best represented by the slope of the regression equations relating leaf conductance to VPD (Fig. 8). The greatest sensitivity of leaf stomata to VPD occurred during April and May when leaves were young (Fig. 3 ). As the leaves aged gradually and became senescent from May to February, stomatal sensitivity to VPD decreased as the slope of the regression increased. The slope became positive following September, after which the $r^{2}$ of VPD : conductance decreased to below 0.50 (Fig. 8). The significance of the variable sensitivity of stomata.to VPD will be discussed later.

Seasonal transpiration characteristics are represented as a diurnal sum of water loss per unit leaf area (Fig. 8). Maximum water loss occurred during July through September when temperature and VPD were maximum. On a per plant basis, this maximum water loss during the summer is magnified because this is also the period of maximum leaf area (Sharifi et al. 1982, 1983, Nilsen et al. 1983).

Other water relations components such as osmotic potential, modulus of elasticity, and turgor potential (see Tyree and Hammel 1972, Tyree and Richter 1981) were derived from pressure-volume analyses. Such analyses done over a diurnal cycle (predawn vs. midday) indicated that a maximum diurnal osmotic adjustment of 0.5-0.7 MPa occurred during June-October (Nilsen et al. 1983). There was considerable variability in water relations components among individuals (Nilsen et al. 1981, 1983) but here we present the mean water relations characteristics for the five studied individuals.

The seasonal osmotic potential at full turgor $\left(\psi_{s}{ }^{100}\right)$ and at the turgor loss point $\left(\psi_{s}{ }^{0}\right)$ (Fig. 9) decreased from late February through August in accordance with increasing environmental water stress. The total sea-
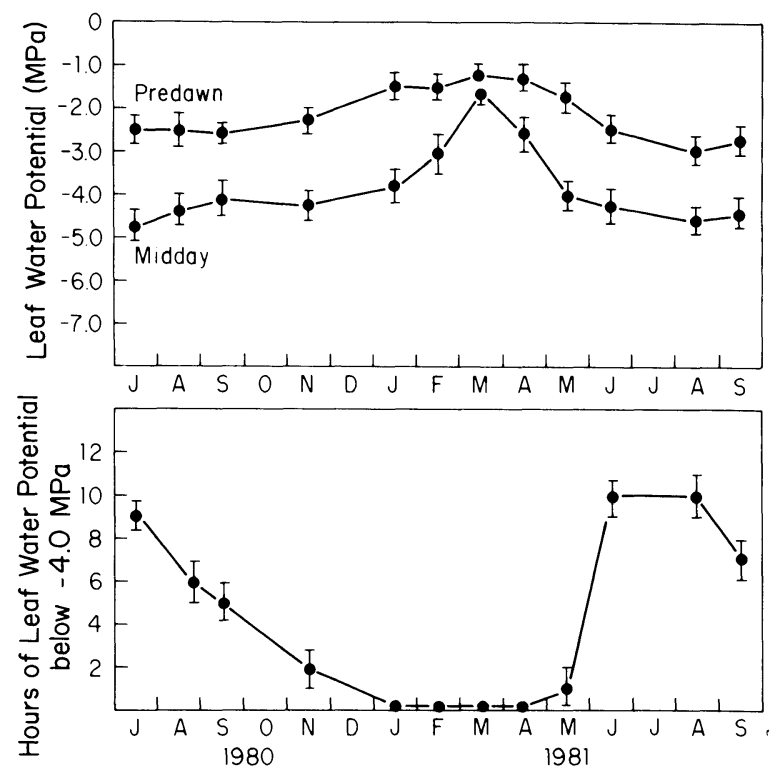

FIG. 7. Seasonal progressions of leaf water potential for five Prosopis glandulosa. 


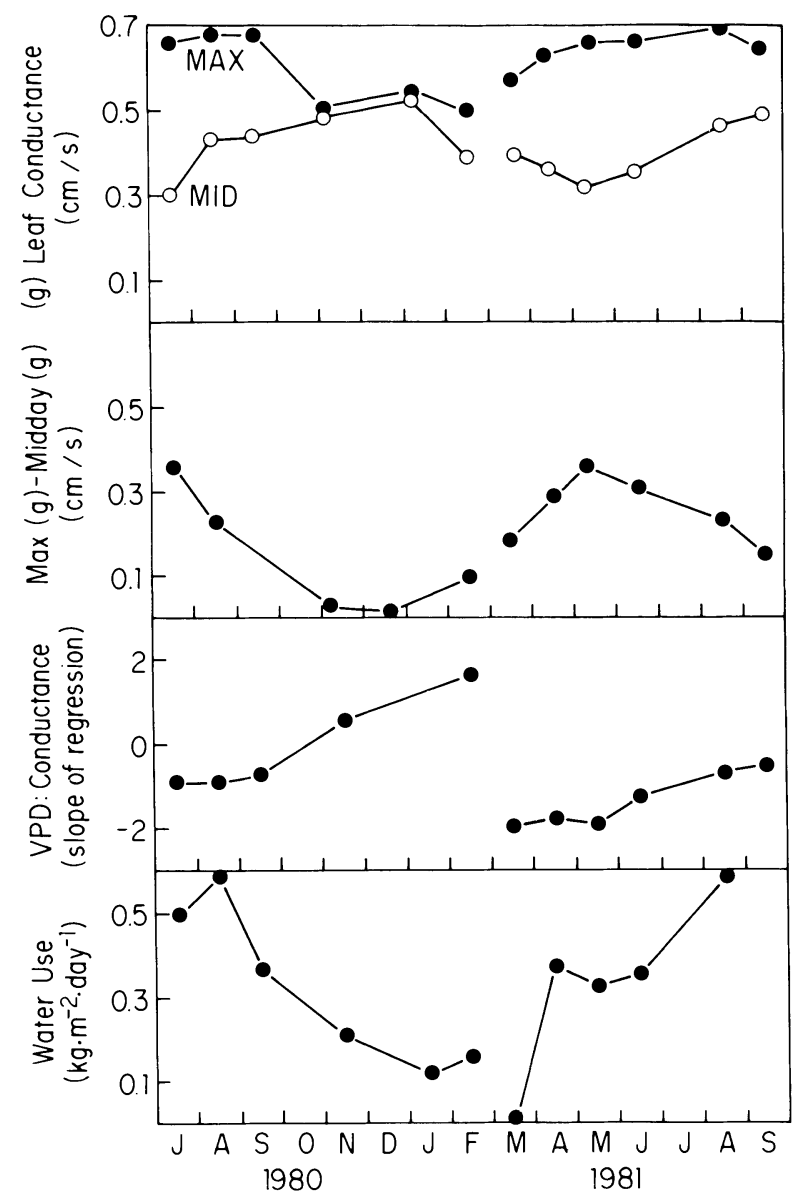

FIG. 8. Seasonal progression of leaf conductance and transpiration characteristics for Prosopis glandulosa.

sonal osmotic adjustment at full turgor was from -1.51 to $-3.30 \mathrm{MPa}$, or a difference of 1.80 MPa. Some individuals had an osmotic adjustment up to $2.5 \mathrm{MPa}$. Osmotic potential at full turgor then increased from August through February as environmental conditions became less stressful. This seasonal osmotic adjustment also coincides with leaf maturation (decreasing osmotic potential) and leaf senescence (increasing osmotic potential) as indicated in Fig. 3. Osmotic potential at zero turgor varied similarly to that at full turgor. In this case the variation was from -1.75 to $-4.20 \mathrm{MPa}$ or $2.45 \mathrm{MPa}$.

The water deficit at the turgor loss point $\left(\mathrm{WD}^{0}\right)$ followed a seasonal pattern similar to that of the osmotic potential. Young leaves in March lost turgor at a WD of 0.17 while mature leaves in July did not lose turgor until they reached a WD of 0.28 . The $W^{\circ}$ decreased from September to February, to a value similar to that of the next year's leaves in March.

Turgor potential was determined from the diurnal cycles of leaf water potential $\left(\psi_{l}\right)$ and the PV-curve relating turgor potential to $\psi_{l}$. The mean, daily mini- mum turgor potential of $0.10 \mathrm{MPa}$ was reached during the early growing season (May) and remained low until November when environmental water stress became less severe. Seasonal dawn turgor potential remained quite stable at $0.80 \mathrm{MPa}$ throughout the measured period. During diurnal cycles of turgor potential of individual plants, zero turgor was occasionally reached from June through August. For example, during August of 1981 turgor potential was lost at 0800 and almost lost at 1600 for the individual used as an example in Fig. 6. From May through November these plants, taken as a group, had minimal mean turgor potential $(<0.1 \mathrm{MPa})$ from 0900 to 1600 , yet stomata remained open.

The modulus of cell elasticity $(E$, calculated as per Cheung et al. 1976) is plotted seasonally as $\bar{E}$ (maximum modulus of elasticity) and $E_{k}$, which represents the slope of $E$ plotted against turgor potential. The modulus of elasticity is an indication of the ability of cells to change volume with decreasing water potential. The larger the $E$, the smaller the cell elasticity. Maximum $E(\bar{E})$ and $E_{k}$ rapidly decreased from March through April (Fig. 9) during the leaf maturation period (Fig. 3). Following leaf maturation, $\bar{E}$ and $E_{k}$ remained

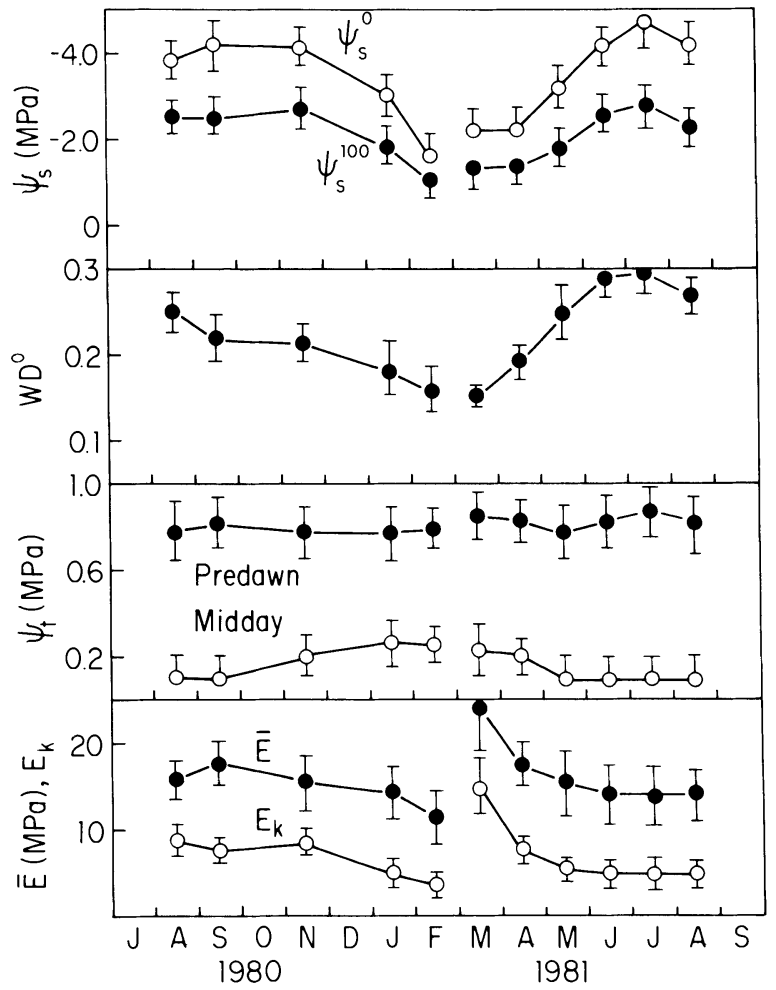

Fig. 9. Seasonal progression of water relations components in Prosopis glandulosa. $\psi_{s}^{100}=$ osmotic potential at full turgor; $\psi_{s}{ }^{0}=$ osmotic potential at incipient plasmolysis; $\mathrm{WD}^{0}=$ relative water deficit at incipient plasmolysis; $\psi_{t}=$ turgor potential; $\bar{E}=$ maximum elastic modulus; $E_{k}=$ slope of line comparing $E$ to RSD. 
constant until November, after which a slight decrease occurred. There is some indication that $\bar{E}$ and $E_{k}$ were slightly lower in 1980 in comparison to 1981 . The seasonal progression of cell elasticity, as measured by $\bar{E}$ and $E_{k}$, was most consistent with leaf maturation and senescence.

\section{Discussion}

\section{Environmental water characteristics}

The climatic data collected at this site in the Sonoran Desert clearly represent extreme conditions of water limitation as indicated by the VPD and the low plant osmotic potentials. This water stress is most severe from May to August when temperatures reach $50^{\circ} \mathrm{C}$, VPD approaches $8 \mathrm{kPa}$, photoperiod is $14 \mathrm{hr}$, wind velocities are high, and irradiance is maximum. These environmental data are similar to those of the most water-limited climates in the California deserts (Hunt 1966, Major 1977) and some of the most stressful deserts of the world (Fuchs 1973). Even though this is a site of extreme aridity (precipitation $=45-65$ $\mathrm{mm}$ ), Prosopis production at this site is the highest measured in desert communities to date (Nilsen et al. 1983, Sharifi et al. 1983); therefore, the Prosopis individuals must be well adapted to conditions of water stress.

Soil moisture characteristics at Harper's Well are unusual for desert environments. Surface soil has very low volumetric moisture content (8-10\%), while deep soils are at or near saturation most of the year. For this reason, and due to high salinity in the surface soil, the surface soil water potential is low in comparison to deep soil. On the basis of the soil-plant-atmospherecontinuum models of water uptake (Nobel 1977: 401408 ) it seems clear that the large majority of water transpired by these Prosopis trees is derived from ground water. Resistance in the 4-m column of water in tap roots would not compensate for the soil water potential gradient from deep to surface soils. Another indication of the minimal root resistance is the rapidity with which the plant water potential returns to the predawn value after sunset (Fig. 5).

\section{Drought avoidance}

The seasonal and diurnal water relations characteristics for Prosopis at Harper's Well indicate mechanisms of both avoidance and tolerance of water stress. Clearly, Prosopis is able to avoid some aspects of water stress by utilizing the deep groundwater. The ability of Prosopis to utilize groundwater was demonstrated in this investigation by the relatively constant seasonal predawn leaf water potential (Fig. 7). Root mats of Prosopis at Harper's Well were found to occur at 10 $100 \mathrm{~cm}$ and again at $400-600 \mathrm{~cm}$. Also, the rapid recovery of leaf water potential after sunset to predawn values, indicates large available water resources. Even though these Prosopis predominantly utilized the water in deep soil, their predawn leaf water potential $(-1.5$ to $-2.8 \mathrm{MPa}$ ) did not match the water potential of the deep soil ( $-0.2 \mathrm{MPa})$. As previously explained, there seems to be minimal stem and root resistance to water flow so that the plants at predawn may become equilibrated with the combined influences of surface and deep soil moisture relationships. In fact, the predawn leaf water potential $(-1.5$ to $-2.8 \mathrm{MPa})$ appeared to equilibrate with the average value of surface $(-3.0$ to $-4.5+\mathrm{MPa})$ and deep $(-0.2 \mathrm{MPa})$ soil water potential. Another investigation of Prosopis water relations in the Atacama Desert (Mooney et al. 1980) indicated that since the plant water potential at night is higher than that of the surface soil, water may flow from deep soil layers and from the plant into surface soils. Although there were similar water potential gradients in this study, the surface soil moisture was so low that increases in soil moisture at night could not be measured. The activity of surface roots, limited to a short period (February-April) by low water potentials the rest of the year, may function predominantly for nutrient accumulation, particularly for nitrogen (Rundel et al. 1982), to complement the amount of nitrogen accumulated by $\mathrm{N}$-fixation (Shearer et al. 1983).

Other phreatophytic species have been demonstrated to have mechanisms which allow avoidance of water stress. For example, Olneya tesota in Arizona does not experience low leaf water potentials (minimum $=$ $-2.5 \mathrm{MPa})$, presumably due to accumulation of water from deep soils (Szarek and Woodhouse 1976, 1977, Monson and Smith 1982). But in this case, annual precipitation was as high as $250-350 \mathrm{~mm}$, in comparison to $70 \mathrm{~mm}$ at Harper's Well. Cercidium seems to maintain high plant water potentials by maintaining leaves for only a short period in winter (Strain 1970, Szarek and Woodhouse 1978).

\section{Drought tolerance}

Although phreatophytes are generally considered to be drought avoiders and water spenders (Levitt 1980), these data for Prosopis indicate several mechanisms of drought tolerance. First of all, the phenological development of Prosopis leaves does not suggest any phenological drought avoidance mechanism (Fig. 3). Maximum leaf area occurs during the hottest and driest part of the year, and leaves which become morphologically senescent remain on the trees until JanuaryFebruary. Both of these temporal leaf characteristics result in maximal water loss of up to $116 \mathrm{Mg} \cdot$ tree $^{-1}$. $\mathrm{yr}^{-1}$ (Nilsen et al. 1983).

One of the mechanisms of drought tolerance in Prosopis is the observed seasonal variation of stomatal control of water loss. Maximal conductance remained $>0.65 \mathrm{~cm} / \mathrm{s}$ from April through September (Fig. 8), even though water potential dropped to $-4.5 \mathrm{MPa}$ in July. The ability to maintain such a high maximum conductance value during summer months was related to the diurnal cycles of conductance. Maximum con- 
ductance occurred in the morning (800-1000, Fig. 5) when leaf water potential was high and the VPD was low. As VPD increased and leaf water potential decreased, conductance decreased until a leaf water potential reached $\approx-4.0$ to $-4.5 \mathrm{MPa}$, at which time an equilibrium was reached. Since the water potential and conductance varied among individuals, this maintenance of a specific water potential by stomatal control is best shown on the basis of an example individual (Fig. 6).

Regressions between mean leaf conductance and other average water relations characteristics resulted in best correlations with VPD. There has been recent evidence that stomatal conductance is well correlated with the VPD in desert and nondesert species (Lange et al. 1969, 1971, Schulze et al. 1974, Hall and Hoffmann 1976). The midday depression in conductance may be best related to the VPD in some species (Tenhunen et al. 1980). Although this is basically true for the mean values of conductance for Prosopis, on an individual basis, a leaf water potential below -4.0 $\mathrm{MPa}$ causes stomatal closure irrespective of the VPD (Fig. 6).

There has been considerable information in the literature concerned with osmotic adjustment as an adaptation to water stress (Hellebust 1976, Hsiao et al. 1976, Osonubi and Davies 1978, Turner and Jones 1980, Meyer and Boyer 1981). Osmotic adjustment in such drought-hardy shrubs may range up to $2.5 \mathrm{MPa}$ (Walter and Stadelman 1974) of adjustment during severe water stress. Prosopis at Harper's Well had a similar value of osmotic adjustment: $2.45 \mathrm{MPa}$. Diurnal osmotic adjustment, also considered an important adaptation to water stress, was present up to $0.7 \mathrm{MPa}$ in these Prosopis (Nilsen et al. 1983). The seasonal and diurnal osmotic adjustment resulted in the maintenance of turgor potential, found to be critical for drought avoidance (Hsiao 1973), throughout the season.

Plants can adapt to seasonal water stress through osmotic adjustment or by alterations in the bulk elastic modulus, which is an indication of cell wall elasticity (Tyree and Hammell 1972, Cheung et al. 1976, Roberts et al. 1981). Maximum measured elastic modulus $(\bar{E})$ decreased from March through April, as did $\left(E_{k}\right)$, the relationship between $E$ and turgor potential. Therefore, cellular elasticity increased as leaves matured from March through April, but after leaf maturation there was little change in cellular elasticity. There is no evidence for turgor maintenance by adjusting cellular elasticity during periods of extreme water stress, as was reported for several Sonoran desert plants (Monson and Smith 1982).

The relationship between turgor potential, water deficit, and cell elastic modulus (Fig. 10A, B) is critical to understanding the way in which Prosopis adjusts its water relations in response to severe water stress. During June (high water stress) the leaves of Prosopis
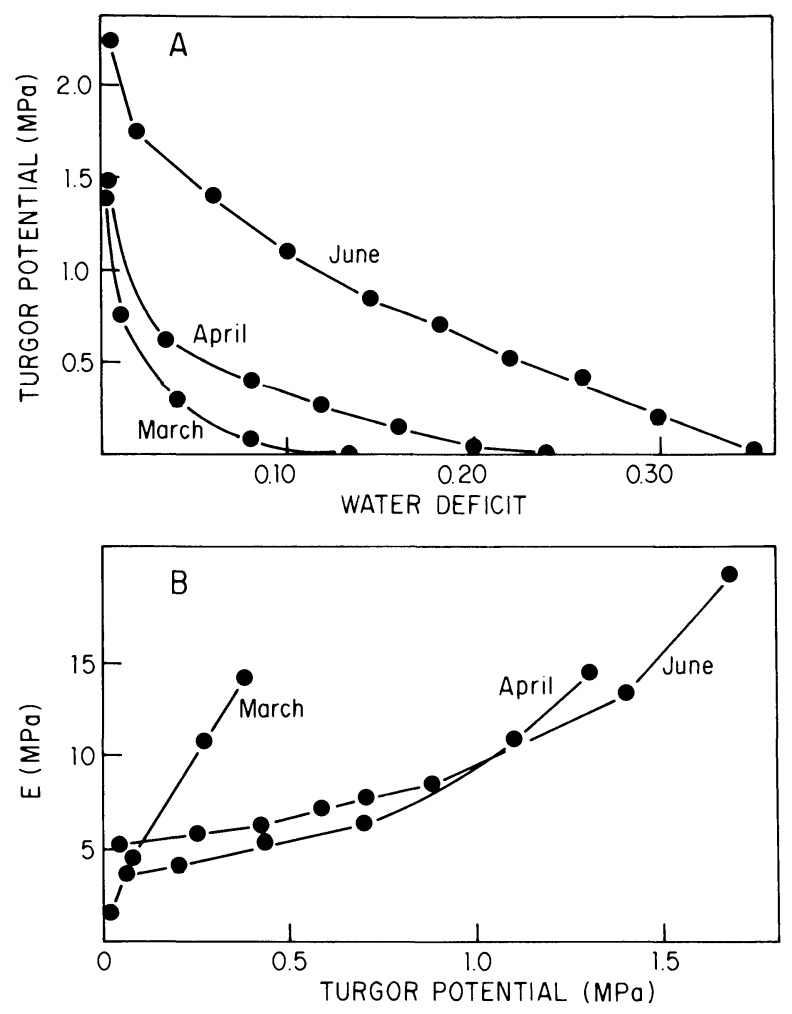

FIG. 10. Relationships of turgor potential, water deficit, and modulus of elasticity for leaves during March, April, and June (1981) on Prosopis glandulosa.

are able to maintain turgor to lower leaf water contents (higher water deficits) than the same leaves in March and April (Fig. 10A). Since turgor potential is vital for growth and photosynthesis of plants (Hsiao et al. 1976), the ability to maintain turgor at high water deficit is an important adaptation to the severe water stress conditions of the Sonoran desert. Turgor potential can be maintained at low leaf water content either by an adjustment of cell volume through cellular elasticity or an adjustment of osmotic potential. Often the maximum elastic modulus $(\bar{E})$ is used as an indication of possible adjustment of cell elasticity (Monson and Smith 1982), but there are many reasons why this value may contain considerable variability (Cheung et al. 1976, Roberts et al. 1981) and error (Tyree and Richter 1982). The best measure of the variation in cell elasticity is a comparison of the way in which $E$ changes with turgor potential $\left(E_{k}\right)$. There was no difference in the relationship between $E$ and turgor potential for Prosopis when comparing April to June values (Fig. 10B). However, there is a considerable influence of leaf maturation on this relationship because March values (immature leaves) are quite different from those of April and June (mature leaves). These data indicate that changes in cell elasticity are due to leaf development, rather than a response to water stress. Pro- 


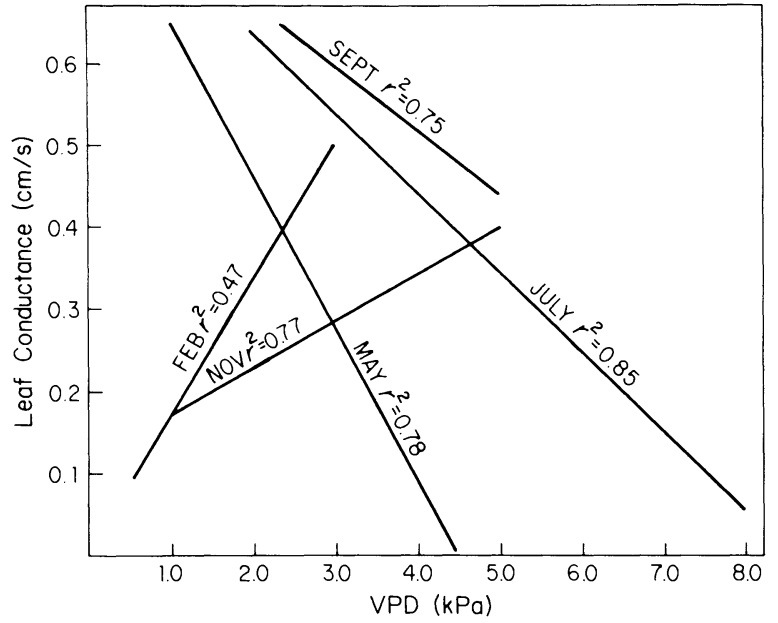

FIG. 11. Regressions between VPD and conductance for different aged leaves in a field population of Prosopis glandulos $a$. May $=2$ mo old, July $=4$ mo old, September $=6$ mo old, November $=8$ mo old, February $=11$ mo old.

sopis responds to water stress by adjusting osmotic potential (Fig. 9) after leaf maturation, thereby maintaining turgor potential at low leaf water contents.

Some researchers have argued that rapid loss of turgor at relatively low WD may be an adaptation allowing water conservation in times of severe water stress (Monson and Smith 1982). Rapid loss of turgor would cause stomatal closure and this would result in water conservation. This may be reasonable for shallowrooted evergreen species which have small water resources and large evaporative demand in summer months when major leaf area is maintained. But these species, such as Larrea tridentata, generally have sclerophyllous leaves which maintain turgor to low leaf water contents. Also, maintaining a large leaf area with closed stomata creates considerable problems for the leaf energy budget in environments with high irradiance (Nobel 1977), and photo-oxidation of photosystems can result. Therefore, water conservation by rapid loss of turgor at high leaf water content would seem to be a disadvantage to water stress in desert plants, especially since growth and photosynthesis are severely curtailed by loss of turgor potential. On the other hand, the ability to maintain turgor at low leaf water content has clear advantages for plants in arid regions, since conductance can be maintained and growth can continue.

\section{Influences of leaf age}

Leaf age (and/or development) clearly influences leaf water relations characteristics. The phenology of leaf production in Prosopis (Fig. 3) results in an even-aged cohort of leaves produced in March. After production the leaves mature rapidly, as indicated by leaf specific mass which becomes constant in early April (Rundel et al. 1982). The main cohort of leaves then remains mature until early September when the first signs of senescence appear. Juvenile leaves have lower osmotic potentials at full turgor and reach incipient plasmolysis at a lower WD (Nilsen et al. 1981). This suggests that the seasonal osmotic adjustment (Fig. 9) might be a result of leaf maturation, not a response to increasing water stress, from February to July. But leaves mature (based on specific leaf mass and leaf area) by late April (see Fig. 3 and Sharifi et al. 1983) while most osmotic adjustment occurs between April and June. Therefore, the major portion of observed seasonal osmotic adjustment is most associated with increasing water stress, not with leaf morphological maturation.

There also seems to be a relationship between leaf conductance and leaf age. First of all, the largest midday depression in leaf conductance occurred during April and May, while the greatest environmental water stress did not occur until June through August. This suggests that stomata are more sensitive to the VPD and leaf water potential during the late spring (AprilMay) and when they are young mature leaves. During April and May turgor potential is lost at a higher water potential and lower $\mathrm{WD}^{0}$, which is one reason why conductance is more sensitive to changes in leaf water potential in April + May as compared to June to September. Furthermore, the regression between VPD and leaf conductance varies with leaf age (Fig. 8), as plotted in Fig. 11. As the leaves age ( $1 \mathrm{mo}$ to $6 \mathrm{mo}$ ) the slope of the regressions becomes less steep but remains negative. Therefore, at a VPD of $4.0 \mathrm{KPa}$ in May and July, leaf conductance will be $0.10 \mathrm{~cm} / \mathrm{s}$ and $0.60 \mathrm{~cm} / \mathrm{s}$, respectively. As drought stress becomes more severe, higher conductances are maintained at lower VPD due to the change in slope of the VPD : conductance regression. Higher leaf conductances (and higher photosynthetic rates) can be maintained in July due to the changing association of VPD with leaf conductance. Following the initiation of senescence (September) the VPD: conductance regressions became positive and had a poorer fit $\left(r^{2}=0.47-0.77\right)$. This suggests a fundamental change in stomatal control following early signs of senescence.

The data collected during this investigation indicate that Prosopis by its phreatophytic habit can avoid severe physiological water stress as defined by loss of turgor, severely reduced leaf conductance, or reduced growth. However, this study also indicated that this phreatophytic species has several mechanisms of tolerating drought stress such as seasonally changing stomatal sensitivity to VPD, and seasonal and diurnal osmotic adjustment to maintain turgor potential during severe environmental drought. These mechanisms of avoiding and tolerating water stress are highly adaptive in desert wash envirionments, because they allow relatively high productivity (Salinas and Sanchez 1971 , Sharifi et al. 1983) in environments with extreme aridity. 


\section{ACKNowledgments}

This research was supported by National Science Foundation grant number DEB 79-21971. Our thanks to Karin Christensen for graphics.

\section{Literature Cited}

Adams, M. S., and B. R. Strain. 1968. Photosynthesis in stems and leaves of Cercidium floridum: spring and summer diurnal field response and relation to temperature. Oecologia Plantarum 3:285-297.

Anderson, D. A., and S. R. Szarek. 1981. Ecophysiological studies on Sonoran desert plants. VI. Seasonal photosynthesis and production of Macheranthera gracilis, a winter ephemeral. Plant Cell and Environment 4:243-250.

Bennert, W. H., and H. A. Mooney. 1979. Water relations of some desert plants in Death Valley, California. Flora 168:405-427.

$\rightarrow$ Biscoe, P. V., Y. Cohen, and J. S. Wallace. 1976. Daily and seasonal changes of water potential in cereals. Philosophical Transactions of the Royal Society of London B 273:565-580.

$\rightarrow$ Cable, D. R. 1977. Seasonal use of soil water by mature velvet mesquite. Journal of Range Management 30:4-11.

Cheung, Y. N. S., M. T. Tyree, and J. Dainty. 1976. Some possible sources of error in determining bulk elastic moduli and other parameters from pressure volume curves of shoots and leaves. Canadian Journal of Botany 54:758-765.

Cunningham, G. L., and B. R. Strain. 1969. Ecological significance of seasonal leaf variability in a desert shrub. Ecology 5:400-408.

Ehleringer, J., and H. A. Mooney. 1983, in press. Photosynthesis and productivity of desert and mediterraneanclimate plants. In O. L. Lange, P. S. Nobel, C. S. Osmond, and $\mathrm{H}$. Ziegler, editors. Encyclopedia of plant physiology 14, Part D. Springer-Verlag, New York, New York, USA.

Felker, P. 1979. Mesquite: an all purpose leguminous arid land tree. Pages 89-132 in G. A. Ritchie, editor. New agricultural crops. American Association for the Advancement of Science, Boulder, Colorado, USA.

Fonteyn, P. J., and B. E. Mahall. 1978. Competition among desert perennials. Nature 275:544-545.

Fuchs, M. 1973. Climate and irrigation. Pages 143-152 in B. Yaron, E. Danfors, Y. Vaadia, editors. Arid zone irrigation. Springer-Verlag, New York, New York, USA.

Gardner, W. H. 1965. Water content. In C. A. Black, editor. Methods of soil analysis. Part 1. Agronomy 9:82-127.

$\rightarrow$ Gulmon, S. L., and H. A. Mooney. 1977. Spatial and temporal relationships between two desert shrubs, Atriplex hymeneolytra and Tidestromia oblongifolia in Death Valley, California. Journal of Ecology 65:831-838.

$\rightarrow$ Haas, R., and J. Dodd. 1972. Water stress patterns in honey mesquite. Ecology 53:674-680.

Hall, A. E., and C. J. Hoffmann. 1976. Leaf conductance responses to humidity and water transport in plants. Agronomy Journal 68:876-881.

Hastings, J. R., R. M. Turner, and D. K. Warren. 1972. An atlas of some plant distributions in the Sonoran Desert. Technical reports on the meteorology and climatology of arid regions, Number 21. Institute of Atmospheric Physics, University of Arizona, Tucson, Arizona, USA.

Hellebust, J. A. 1976. Osmoregulation. Annual Review of Plant Physiology 27:485-507.

Hellmuth, E. O. 1971. Ecophysiological studies on plants in arid and semiarid regions in Western Australia. III. Comparative studies on photosynthesis, respiration, and water relations of ten arid zone and two semi-arid zone plants under winter and late summer climatic conditions. Journal of Ecology 59:225-259.

Hsiao, T. C. 1973. Plant responses to water stress. Annual Review of Plant Physiology 24:519-570.

$\rightarrow$ Hsiao, T. C., E. Acevedo, E. Fereres, and D. W. Henderson.
1976. Water stress, growth and osmotic adjustment. Philosophical Transactions of the Royal Society of London, Series B 273:479-500.

Hunt, C. B. 1966. Plant ecology of Death Valley, California. United States Geological Survey Professional Paper 509: $1-68$.

Klepper, B. 1968. Diurnal patterns of water potential in woody plants. Plant Physiology 43: 1941-1946.

Lange, O. L., R. G. Klepper, and R. Cumming. 1969. Leaf water balance during oscillation of stomatal aperture. Plant Physiology 44:826-830.

Lange, O. L., R. Lösche, E. D. Schulze, and L. Kappen. 1971. Responses of stomata to changes in humidity. Planta 100:76-86.

Levitt, J. 1980. Responses of plants to environmental stress. II. Water, radiation, salt, and other stresses. Academic Press, New York, New York, USA.

Major, J. 1977. California climate in relation to vegetation. Pages 11-74 in M. G. Barbour and J. Major, editors. Terrestrial vegetation of California. John Wiley and Sons, New York, New York, USA.

McGinnes, W. G., and J. F. Arnold. 1939. Relative water requirement of Arizona range plants. Technical Bulletin Number 80, University of Arizona Experimental Station, University of Arizona Press, Tucson, Arizona, USA.

Meinzer, O. E. 1927. Plants as indicators of groundwater. Water Supply Paper 577, United States Geological Survey, Washington, D.C., USA.

Meyer, R. F., and J. S. Boyer. 1981. Osmoregulation, solute distribution and growth in soybean seedlings having low water potential. Planta 151:482-489.

Monson, R. K., and S. D. Smith. 1982. Seasonal water potential components of Sonoran Desert plants. Ecology 63: $113-123$.

Mooney, H. A., S. L. Gulmon, P. W. Rundel, and J. Ehleringer. 1980. Further observations on the water relations of Prosopis tamarugo of the northern Atacama Desert. Oecologia (Berlin) 44:177-180.

$\rightarrow$ Mulroy, T. W., and P. W. Rundel. 1977. Annual plants: adaptations to desert environments. Bioscience 27:109-114.

National Oceanic and Atmospheric Administration. 1980. Climatological data-California. Volume 84(7-13) 85(1-7). Environmental Data and Information Service, National Climatic Center, Asheville, North Carolina, USA.

Nilsen, E. T., and W. H. Muller. 1981. Phenology of the drought-deciduous shrub Lotus scoparius: climatic controls and adaptive significance. Ecological Monographs 51: 323-341.

Nilsen, E. T., P. W. Rundel, and M. R. Sharifi. 1983, in press. Patterns of variation in the water relations components of woody desert phreatophytes. Botanical Gazette.

Nilsen, E. T., M. R. Sharifi, and P. W. Rundel. 1981. Summer water relations of the desert phreatophyte Prosopis glandulosa in the Sonoran desert of California. Oecologia (Berlin) 50:271-276.

Nilsen, E. T., M. R. Sharifi, and P. W. Rundel. 1982. Productivity and water use of native stands of the desert phreatophyte Prosopis glandulosa (honey mesquite) and some management implications. California Riparian Ecosystem Symposium, September, 1981. University of California, Davis, California, USA.

Nobel, P. 1977. Introduction to biophysical plant physiology. W. H. Freeman, San Francisco, California, USA.

Odening, W., B. R. Strain, and W. C. Oechel. 1974. The effects of decreasing water potential on the net $\mathrm{CO}_{2}$ exchange of intact desert shrubs. Ecology 55: 1086-1095.

Osmond, C. B., O. Bjorkman, and D. J. Anderson. 1980. Physiological processes in plant ecology. Toward a synthesis with Atriplex. Springer-Verlag, Berlin, Germany.

Osonubi, O., and W. J. Davies. 1978. Solute accumulation 
in leaves and roots of woody plants subjected to water stress. Oecologia (Berlin) 32:323-332.

Parker, K. W., and S. G. Martin. 1952. The mesquite problem on southern Arizona range. Circular 968, United States Department of Agriculture, Washington, D.C., USA.

$\rightarrow$ Phillips, W. S. 1963. Depth of roots in soil. Ecology 44: 424.

Roberts, S. W., B. R. Strain, and K. R. Knoerr. 1981. Seasonal variation in leaf tissue elasticity in four forest tree species. Physiologia Plantarum 52:245-250.

Rundel, P. W., E. T. Nilsen, M. R. Sharifi, R. A. Virginia, W. M. Jarrell, D. H. Kohl, and G. B. Shearer. 1982. Seasonal dynamics of nitrogen cycling for a Prosopis woodland in the Sonoran Desert. Plant and Soil 67:343-353.

Salinas, H. E., and S. C. Sanchez. 1971. Estudio del tamarugo como productor de alimento del ganado lanar en la Pampa del Tamarugal. Informe. Tecnico Numero 38, Seccion Silvicultura, Instituto Forestal, Santiago, Chile.

Scholander, P. F., H. T. Hammel, E. D. Bradstreet, and E. A. Hemmingsen. 1965. Sap pressure in vascular plants. Science 148:339-346.

Schulze, E. D., O. L. Lange, M. Evenari, L. Kappen, and U. Buschbom. 1974. The role of air humidity and leaf temperature in controlling stomatal resistance of Prunus armeniaca $\mathrm{L}$. under desert conditions. I. A simulation of the daily course of stomatal resistance. Oecologia (Berlin) 17:159-170.

$\rightarrow$ Sharifi, M. R., E. T. Nilsen, and P. W. Rundel. 1982. Biomass and net primary production of Prosopis glandulosa (Fabaceae) in the Sonoran desert of California. American Journal of Botany 69:760-767.

Sharifi, M. R., E. T. Nilsen, R. A. Virginia, and P. W. Rundel. 1983. Phenological patterns of current season shoots in Prosopis glandulosa in the Sonoran Desert of southern California. Flora 173:265-277.

Shearer, G., D. H. Kohl, R. A. Virginia, B. A. Bryan, J. L. Skeeters, E. T. Nilsen, M. R. Sharifi, and P. W. Rundel. 1983. Estimates of $\mathrm{N}_{2}$-fixation from variation in the natural abundance of ${ }^{15} \mathrm{~N}$ in Sonoran Desert ecosystems. Oecologia (Berlin) 56:365-373.

$\rightarrow$ Smith, W. K., and P. S. Nobel. 1977. Influences of seasonal changes in leaf morphology on water-use efficiency for three desert broadleaf shrubs. Ecology 58: 1033-1043.

$\rightarrow$ Strain, B. R. 1969. Seasonal adaptation in photosynthesis and respiration in four desert shrubs growing in situ. Ecology 50:511-513.

_ 1970. Field measurements of tissue water potential and carbon dioxide exchange in the desert shrubs Prosopis julifora and Larrea divaricata. Photsynthetica 4:118-122.

Szarek, S. R., and R. M. Woodhouse. 1976. Ecophysiological studies of Sonoran desert plants. I. Diurnal photosynthetic patterns of Ambrosia deltoidea and Olnea tesota. Oecologia (Berlin) 26:226-234.
Szarek, S. R., and R. M. Woodhouse. 1977. Ecophysiological studies of Sonoran desert plants. II. Seasonal photosynthesis patterns and primary production of Ambrosia deltoidea and Olnea tesota. Oecologia (Berlin) 28:365-375.

Szarek, S. R., and R. M. Woodhouse. 1978. Ecophysiological studies of Sonoran desert plants. III. Daily course of photosynthesis for Accacia greggii and Cercidium microphyllom. Oecologia (Berlin) 35:285-294.

Tenhunen, J. D., O. L. Lange, M. Braun, A. Meyer, R. Losch, and J. S. Pereira. 1980. Midday stomatal closure in Arbutus unedo leaves in a matorral macchia and under simulated habitat conditions in an environmental chamber. Oecologia (Berlin) 47:365-367.

Turner, N. C., and M. M. Jones. 1980. Turgor maintenance by osmotic adjustment: a review and evaluation. Pages 87 103 in N. C. Turner and P. J. Kramer, editors. Adaptation of plants to water and high temperature stress. John Wiley and Sons, New York, New York, USA.

Tyree, M. T., and H. T. Hammell. 1972. The measurement of the turgor pressure and water potential of plants by the pressure bomb technique. Journal of Experimental Botany 23:267-282.

Tyree, M. T., and H. Richter. 1981. Alternative methods of analyzing water potential isotherms: some cautions and clarifications. I: The impact of non-ideality of some experimental errors. Journal of Experimental Botany 32:643653

Tyree, M. T., and H. Richter. 1982. Alternate methods of analyzing water potential isotherms: some cautions and clarifications. II. Curvilinearity in water potential isotherms. Canadian Journal of Botany 60:911-916.

Von Hylckama, T. E. A. 1969. Photosynthesis and water use by Salt Cedar. International Association of Hydrology, Bulletin 14:71-83.

Virginia, R. A., and W. M. Jarrell. 1983. Soil properties in a Mesquite-dominated desert ecosystem. Soil Science Society of American Journal 47:138-144.

Virginia, R. A., W. M. Jarrell, D. H. Kohl, and G. B. Shearer. 1981. Symbiotic nitrogen fixation in a Prosopis (Leguminosae) dominated desert ecosystem. Page 483 in $\mathrm{A}$. H. Gibson and W. E. Newton, editors. Current perspectives in $\mathrm{N}_{2}$-Fixation. Proceedings of the Fourth international symposium on nitrogen fixation, 1-5 December 1980. Australian Academy of Science, Canberra, Australia.

Walter, H., and E. Stadelman. 1974. A new approach to the water relations of desert plants. Pages 213-310 in J. W. Brown, editor. Desert biology. Volume II. Academic Press, New York, New York, USA.

Webb, W., S. Szarek, W. Lauenroth, R. Kinerson, and M. Smith. 1979. Primary productivity and water use in native forest, grassland and desert ecosystems. Ecology 59: $1239-1247$. 